\title{
Classification and Organization in a School System
}

For a while after [the 1949 War of] Liberation... even those intellectuals like ourselves from old liberated areas [in northern China] were able to shake off the [kinds of political] discrimination that we had long endured [within the Chinese Communist movement] and became "veteran cadres"... going from being persecuted to becoming persecutors.

-WEI JUNYI, CA. 1991

During the mid-1930s, Wei Junyi (1917-2002) was a philosophy major and political activist at the prestigious Tsinghua University in Beijing. She was so inspired by what she learned in her spare time about the CCP and its resistance to the ongoing Japanese invasion of China that she joined the party in 1936 and went to Yan'an three years later. Like many young people in the remote town during this period, she specialized in literary and educational work, traveled with Red Army troops, and performed subsistence agricultural labor. That is, she became an "intellectual" under the Mao regime. When the Rectification Campaign sponsored by the regime descended during the 1940 s into the Rescue Campaign (Qiangjiu yundong), a ferocious hunt for spies and traitors in the ranks of revolutionaries within the ShaanGan-Ning base area, Wei was working in a town near Yan'an. ${ }^{1}$ She initially believed the extraordinary tales of conspiracy and betrayal reported by the local party leaders, including their discovery of female students using sex and romance as bait to gather intelligence for the Guomindang and of enemy agents as young as six years of age. As close friends and eventually her husband were detained and identified as spies by the authorities, she realized that false accusations had been widespread. To avoid further punishment, her husband concocted self-incriminating stories with her support and, like many others, confessed publicly to trumped-up charges. With her trust in the local leadership shaken, Wei wrote to Chairman Mao to seek justice. Her husband even went to Yan'an to try to clear his name, only to find out that the abuses there had been still worse. Shortly afterward, Mao and his deputies issued public apologies for maltreating revolutionaries, which was small 
consolation to Wei and her husband, who had lost their child to illness partly because of the strain and isolation suffered by the family when it was under attack. ${ }^{2}$

Anyone who expects that Wei's loss and trauma as a Yan'an revolutionary would have hardened her into a noble woman daring to stand up against injustices under Chinese Communism will be disappointed. When she and her husband returned to Beijing during the late 1940 s to assist in the CCP takeover, what they saw was a bizarre and depraved city, a far cry from how they had experienced the place before joining others in Yan'an. Filled with joy and confidence, they considered themselves part of the righteous forces that would remake Beijing from top to bottom. As successive punitive campaigns swept across the city during the first years of CCP rule, Wei, who worked in propaganda and literature, responded almost exactly as she had during her Yan'an years. At first, she believed the charges brought against others by the authorities. When the latter denounced her friends and colleagues, she recognized the baselessness, injustice, and even absurdity of the accusations. Nonetheless, she participated in and even led the persecution of colleagues of whose innocence she was certain. When she or her husband became a target of attack, they exploited their connections to higher officials to shield themselves from or minimize the resulting humiliation and punishment. In her own words, she "carried on the abominable practice of political persecution that the Mao regime deemed to be appropriate and beneficial to CCP rule."3

In this chapter, we move our investigation of the mutual constitution of the intellectual and Chinese Communism into the postrevolutionary workplace. A Marxist-Leninist dictatorship, the Mao regime was determined to industrialize China. The regime appointed large numbers of CCP cadres officially classifiable as intellectuals, especially those who had joined the party before 1949, to colleges, newspapers, factories, and other establishments to oversee those whom it labeled intellectuals, while the state media unceasingly criticized the politics, knowledge, and character of such subjects. Management by party cadres, ideological reeducation, and mass surveillance became features of such establishments and led to an unending flow of texts, signs, and cues that reproduced the official discourse of class. Ordinary professional workers (e.g., journalists, accountants, engineers) not only were objectified into usable but unreliable intellectuals for all to see; they were divided further into various subtypes for purposes of political control. To deflect their own stigmatization by the state, the cadres distanced themselves from the professional workers through various means. As Wei Junyi hinted in the epigraph, many represented themselves in words or deeds as "veteran cadres" (lao ganbu) by drawing attention to their loyalty to, sacrifices for, and knowledge of Chinese Communism. As the professional workers coped with official criticisms of selfishness, indiscipline, and other failings and the often callous behavior of the cadres, professional life became infected with fear and anger, shame and resentment, pretension and deception as well as antagonism, withdrawal, and humiliation. The domination, division, and demoralization impeded the 
official goal of rallying party cadres and professional workers to build a successful socialist polity together.

To use the terminology of the late sociologist Erving Goffman, the CCP takeover of industry, education, and other sectors based on the official discourse of intellectuals created two vulnerable populations. The discredited comprised ordinary professional workers, or those who fit precisely into the Marxian definition of intellectuals of the party. They were subjects of state disparagement and objects of political control. The discreditable included party cadres who were relatively educated and thus susceptible to being categorized as intellectuals by superiors and others. As members of the two populations engaged in stigma management, or efforts to reduce the damage that the classification would do to them, a culture of anxiety, distrust, and resentment grew increasingly to mar the workplace. This outcome could not but harm the prospect of Chinese Communism. ${ }^{4}$

To clarify these aspects of the intellectual and Chinese Communism under the early PRC, I discuss conditions within Shanghai secondary education as well as professional life in the city, especially during Thought Reform of Intellectuals. Twelve years ago, I published a book on the school system. The book illustrates the bureaucratic quagmire that developed in the workplace because of state conduct and the resulting challenges to official governance. ${ }^{5}$ As I turned my attention again to the postrevolutionary workplace with themes of this book in mind, I kept noticing dynamics similar to those obtaining in the school system in documents on higher education, industry, and other sectors that I came across in the municipal archives of Shanghai and Beijing. I realized that with the wealth of material I had gathered on the school system over an eight-year period, I could offer a rich yet succinct example of how the workplace figured in the mutual constitution of the intellectual and Chinese Communism, while reminding the reader that any similar survey of another sector must take into consideration its institutional characteristics (such as division of labor, control mechanisms, and management decisions). The following account contains primarily data that did not appear in my previous book.

More specifically, I suggest that two interrelated bundles of administrative conduct saturated the urban workplace, served to objectify the intellectual, and shaped social relations and individual calculus. First, I use textual corroboration to refer to the multiple layers of documentation that party cadres maintained on the staff on the basis of the official discourse of class. The records appeared in many genres of text (e.g., staff registration, autobiographical narrative, performance appraisal, police report, penalty statement), each corresponding to specific investigative efforts of the state. The records covered, to varying extents, the family background, occupational history, work performance, social connections, political activities, and outlook and habits of the individual. The documents consistently described most professional workers as petty-bourgeois intellectuals and ascribed to these workers preconceived habits and dispositions from the official discourse. 
They also identified a minority of such workers virtually as enemies of the state. Second, I use everyday signification to refer to the deluge of signs and cues initiated by the party cadres that reinforced the official representation of ordinary professional workers as petty-bourgeois intellectuals. Some of these signs and cues went together with mandated organizational reform; others arose as the cadres signaled that they were politically and morally superior to ordinary professional workers. Work arrangement, staff meetings, everyday interaction, and other workplace activities were impregnated with terms, meanings, and values from the official discourse of intellectuals, sometimes in a dramatic fashion.

\section{CLASSIFICATION IMPACT OF TEXTUAL CORROBORATON}

Sociologist Dorothy Smith argues that "textual reality" is integral to systemic domination. States and other organized powers create their own written accounts of people, things, and events. Built upon "the discourse of ruling" of these powers, or their political and administrative visions, the accounts produce "objectified forms of knowledge." Issues are formulated, studied, and recorded "because they are administratively relevant, not because they are significant first in the experience of those who live them." When the PLA entered Shanghai in mid-1949, the CCP had more than 700 underground agents serving as faculty or staff members across primary and secondary schools. ${ }^{7}$ These agents organized teacher associations, set up student groups, promoted street demonstrations, and conducted other activities on behalf of Chinese Communism. ${ }^{8}$ Some of these agents had prepared reports on the character, performance, and politics of colleagues in anticipation of campus takeovers by the party. Composed under secrecy, such reports lacked substance and accuracy compared with material assembled later by party cadres through various means of official surveillance. The reports, nonetheless, marked the introduction of textual corroboration into the school systems, or the textual reality of the party based on its discourse of class.

Wuben Girls Secondary School (Wuben nüzi zhongxue), which was founded in 1902, had the distinction of being China's first secondary school for girls. The campus was quickly taken over by the CCP authorities after they seized control of the Shanghai Municipal Bureau of Education (hereafter SBE) (Shanghaishi jiaoyuju) in June 1949 and tasked it with reorganizing primary and secondary education and instructional programs of various kinds. A few weeks later, an underground agent who had taught at Wuben for two years delivered to the bureau a ninepage report on the faculty and staff. This handwritten report, which was about 7,000 characters long, focused on management personnel and whether they were fit to keep their jobs. School principal Yang Minghui, who had allegedly fled to Taiwan after purchasing an exquisite apartment there with embezzled money, was depicted as a villain and virtually part of the exploiting classes. She was a 
"typical dirty party politician" of the Guomindang who had sat on its legislative and governing bodies and had obtained her campus position through ties to powerful officials. She traveled ostentatiously by car or rickshaw, smoked heavily, wore expensive clothing and heavy makeup, and indulged herself in playing mahjong and other activities unbecoming of educators. Had Yang stayed on campus, the SBE would have removed her from her position and very possibly worked with other emerging state agencies to have her arrested. Forty other faculty or staff members appear in the report as usable but unreliable intellectuals, but also to different extents. Three components loom large in these brief assessments. First, appraisals of work performance, or the functional value of the individual to the institution of education, range from "well-learned" and "dedicated to students" to "indifferent" to their duties and "incompetent." Second, descriptors of personal character, or the likelihood that the individual would heed the socialist message of the state, include, for example, kind-hearted, even-tempered, timid, and despicable. Third, political judgments were constant, and sometimes expressed in stock phrases (such as "progressive in thinking" and "emphasizing personal safety first") to signal how the person had reacted to public protests against the Japanese invasion of China or Guomindang rule. Overall, the assessments hinted at how likely it was that the individual would support CCP rule. For example, physics teacher Yuan Chengming was presented as someone who could be trusted, because she was "open-minded" as well as "straightforward and kind" and did not exhibit the materialistic "styles typical of Shanghai people," besides being an instructor well received by students. In contrast, part-time instructor of Chinese literature Zheng Yimei (1895-1992), though well respected in the local literary and art scenes, was depicted as an obstacle to revolutionary change, because he was arrogant, stubborn, self-absorbed, and irresponsible, in addition to clinging to "outmoded ways of thinking" about gender, labor, and other issues. ${ }^{9}$

Within Shanghai secondary education, no event of the early 1950s was as influential as Thought Reform of Intellectuals in supplying a textual reality for objectifying faculty and staff members into "petty-bourgeois intellectuals." The well-documented national campaign, which also targeted professors, writers, and other professional workers, was partly an outcome of textual material gathered about these people by party cadres through investigations and mandated self-reports. The SBE had used pertinent records to identify supporters, remove others from their posts, and implement mechanisms of control on campuses. Thought Reform enabled the bureau to collect material on virtually every faculty and staff member. More than 7,000 of them participated in the campaign in three successive groups between July 1952 and March 1953. ${ }^{10}$ There is no need to detail the activities that defined the campaign, that is, mutual criticism and selfcriticism of the political, moral, and professional wrongdoing of the participants, their writing and rewriting of autobiographical narratives, publication of select compositions on site and in newspapers for instructional purposes, and study of 
state policies and other preassigned topics. The activities were informed by the discourse of intellectuals and the practice of ideological reeducation that the party had developed before taking power. The activities led to countless mentions of the intellectual by individuals and organizations, along with descriptions of what the state expected from such subjects and their supposedly undesirable and even objectionable traits. ${ }^{11}$

The surge of textual material during Thought Reform enabled the SBE to characterize and compare faculty and staff members as class subjects and to highlight the overall distribution of attributes of these "intellectuals." Notwithstanding the presence of false and inaccurate information, the records furnished details of the political, occupational, and family backgrounds of the individuals and their habits and dispositions, social networks, political activities, and responses to CCP rule. Let us look at the main findings of the bureau, or what it most wanted to know about the faculty and staff. Virtually half had allegedly had ties to Guomindang organizations; at least 20 percent were former government officials, military officers, special agents, or political organizers. The SBE singled out some of these people as potentially serious threats to its control of the campuses. These individuals had reportedly served in ranking positions, acted as undercover agents in schools, or participated directly in thwarting student movements against the Guomindang government. The SBE discovered others whom it regarded as former local bullies, landlords, bandits, or religious sect leaders, or people who had used force or other means to take advantage of and even physically hurt others. ${ }^{12}$ On top of this picture of unacceptable political allegiances, outright criminality, and class-enemy backgrounds, the SBE reported large numbers of comparatively minor offenses and transgressions, some of which had occurred shortly before and even during Thought Reform. For example, at Yuedong Secondary School, which had twentyfive faculty and staff members, eight confessed to corruption or other economic wrongdoing and twenty-three to illegal gambling or lending. Fourteen said that they had womanized or patronized dance halls, and ten reported that they had "abominable workstyles" that sometimes involved severe physical punishment of students. Prostitution and syphilis, drug addiction and trafficking, and tax evasion and theft were documented on other campuses. ${ }^{13}$

What happened to physics teacher Cao Qingjun demonstrates further how the textual reality of the SBE turned faculty and staff members into usable but unreliable intellectuals. Using material gathered during Thought Reform and other occasions, the bureau put together a portrait of Cao when seeking to impose punishment on those who had committed wrongdoing recently. First, Cao turned out to be a former Guomindang official. He had served as a military interpreter during the Anti-Japanese War and received Song Meiling (1897-2003) when she visited the town where he worked. Song was the wife of Chiang Kai-shek, the leader of the Guomindang. Second, Cao was greedy, undisciplined, and untrustworthy. He had engaged in economic speculation before and after 1949. He owed money 
to restaurants where he wined and dined, had taken money from students and colleagues, and had stolen from the schools where he worked. Third, Cao was as an unscrupulous instructor. He failed to grade students properly and made improper advances to female students, so much so that he had stolen examination papers and used them as bait to get close to teenagers whom he liked. Despite these findings, the SBE merely issued Cao a formal warning (jinggao) for his behavior, which was one of the lightest sanctions that the bureau could administer. ${ }^{14}$ An almost twofold expansion of student enrollment within the school system between 1949 and 1953 made the bureau reluctant to dismiss any instructors except those considered incorrigible. ${ }^{15}$ Moreover, Cao's punishment, or the lack of it, suggests that he had been cooperative with the authorities during the investigations. In short, he remained usable from the bureau's perspective.

As textual material on the faculty and staff accumulated because of state surveillance, the SBE performed paidui, an official approach to control that was becoming increasingly common. Paidui literally means lining up people or things in order. Administrative documents use the term to refer to the division of a population into a sequence of political subcategories supplied by the higher authorities. The procedure enabled the state to experiment with various schemes of classification and accordingly formulate measures of supervision, punishment, encouragement, and so on. Within the school system, party cadres used gathered documentation and their observations to combine and recombine faculty and staff members into lineups of political subtypes - and therefore produced even more written records on these "intellectuals." What happened at the reputed Nanyang Model Secondary School is instructive. It shows that while the state saw most schoolteachers as petty-bourgeois intellectuals, the use of paidui placed a small minority on the edge of the category of class enemies and even squarely inside it. In the spring of 1952, Nanyang's faculty and staff took part in a pilot run of Thought Reform. After weeks of investigation and ideological reeducation, the cadres had collected sufficient material to place twenty-four of the fifty people into literally five subcategories according to the political activities of the individuals and their cooperation with the authorities, or how much of a threat they posed to the school system and the state. "The first category" included those who had in their backgrounds minor "historical problems" of aiding enemy regimes. A former diplomat and a former director of a Christian church were two of the five people assigned to this subcategory. The authorities assigned another five people to "the third category," which was reserved for individuals who had "serious problems in [their] political history" but "no current activities" against the state. Placed in this subcategory was a woman who had disclosed two decades of service to the Guomindang and ties to former key members of the collaborationist regime during the Anti-Japanese War. A former Guomindang official who reportedly had placed CCP cadres under arrest, engaged in criminal activities, and indirectly caused suicides among his victims was the single member of "the fifth category," or people who had "a debt of 
blood" or were involved in "existing activities" against the state and who had been evasive about such wrongdoing. ${ }^{16}$

After Thought Reform formally began within Shanghai secondary education, faculty and staff members were separated into analytical and administrative subtypes by school party cadres, sometimes repeatedly, to facilitate reorganization and management of the campuses. The principal lineup divided the faculty and staff into five segments-that is, "progressive," "intermediate," "backward," "reactionary," and "counterrevolutionary elements"-according to the political experience of the individuals and their willingness to support or submit to CCP instructions and standards, especially those publicized within the school system. The SBE made recommendations as to the proportion of the faculty and staff to be placed in each segments (for example, approximately 25 and 15 percent were to be designated as progressive and reactionary elements, respectively). ${ }^{17}$ Other political lineups and schemas of subcategories appeared. On the one hand, these instruments reflected official vigilance, or the view that intellectuals constituted a threat to Chinese Communism. On the other hand, they helped to justify the deployment of penal and other administrative measures within the school system, especially the appointment of party cadres to management positions. For the state, the classification further captured the political and class character of some of the faculty and staff members. For instance, by September 1952, after roughly half of the faculty and staff had undergone Thought Reform, the SBE instructed the cadres in charge of the campaign to designate some as "key targets [of attention]" based on evidence or clues of involvement in counterrevolutionary activities or serious crimes. The targets were to be separated into "first," "second," and "third" types according to wrongdoing and willingness to cooperate with the authorities, before the administration of criminal punishment or administrative sanction, of which the bureau included immediate arrest, continual subjection to ideological reeducation, deprivation of political rights, and other measures. ${ }^{18}$ The cadres were instructed to identify another four types of people for removal from campus, demotion, formal reprimand, or warning based on wrongdoing, poor work performance, insufficient remorsefulness, and other factors. Put differently, as Thought Reform proceeded, the bureau used gathered records to establish that some faculty and staff members were objectionable or incompetent, and yet some of them could still be used by the school system. ${ }^{19}$

After Thought Reform, textual material continued to build up within the school system, leaving none of the faculty or staff members an unchanging "intellectual." As official investigation continued, previously unknown details of the political, professional, or other activities of these persons came to light. The state's shifting emphasis on the relations of intellectuals to socialist development affected how the SBE interpreted professional conduct and past activities. The state, furthermore, introduced new schemes of political classification, for example, during the mid-1950s Campaign to Wipe Out Hidden Counterrevolutionaries. As a 
result, the bureau reassessed and reclassified faculty and staff members regularly, even though it continued to regard most of them as petty-bourgeois intellectuals. The vicissitudes of Zhu Shouzhong (1920-1970) illustrate how dramatically the CCP's endless documentation of the background, thought, and behavior of so-called intellectuals altered some of these people's class and political identitiessometimes with life-and-death consequences. When the PLA entered Shanghai, Zhu was already a well-documented supporter of the socialist revolution. When he was a secondary student in the late 1930s, he participated in public protests against Guomindang policies and practices. He subsequently graduated from the Economics Department of the famous Fudan University, but chose to become a schoolteacher. During the civil war, he became an influential member of the Shanghai Secondary School Teachers Association, a front organization established by the CCP to rally support for the revolution. After the takeover, Zhu was one of the first Shanghai schoolteachers recruited into the CCP. His education, hard work, and service to the profession earned him the posts of school inspector and then deputy director of teacher-training programs at the SBE. In 1954, the bureau made him the deputy principal of a teachers' college. If Zhu's success exemplified from the official perspective what a supportive petty-bourgeois intellectual could achieve under CCP rule during the early 1950s, he discovered shortly afterward how other facets of his life, once documented officially, would destroy the career and lifestyle that he had worked for. When Land Reform reached his native place after the 1949 revolution, the authorities categorized Zhu as an absentee landlord because of land he had received from his father. We do not know how Zhu had handled the land prior to the campaign. But he did tell some colleagues about the worrisome classification. Nothing disturbing happened to him until the Campaign to Wipe Out Hidden Counterrevolutionaries swept across education and other sectors. The record that he was an absentee landlord became the basis on which his CCP membership was revoked. During the Antirightist Movement roughly a year later, his landlord classification was brought up again at his expense. The SBE accused Zhu of having lied about his class background and sentenced him as "a class adversary who had infiltrated the party" (jieji yizi fenzi). He was reassigned with 500 other people from Shanghai's cultural and educational sectors to the forbidding Ningxia Hui Autonomous Region in northern China, where he was repeatedly denounced and finally executed in $1970 .{ }^{20}$ Once a trustworthy intellectual to the state based on official documentation, Zhu became a class enemy from the official perspective, equally because of textual corroboration.

\section{DYNAMICS OF EVERYDAY SIGNIFICATION}

Following Lenin, the CCP leadership believed that if intellectuals were not placed under the supervision of the party after the socialist revolution, they would continue to use their knowledge and authority to serve the interests of the exploiting 
classes. Using well-trained party cadres to take over banks, newspapers, universities, and other places where intellectuals normally work is vital to advancing socialist development, not to mention defeating any of their attempts at counterrevolution. As soon as the PLA seized Shanghai, party cadres began to move into Shanghai secondary education. Their work engendered an abundance of signs and cues that reinforced the official representation as well as textual corroboration of faculty and staff members as usable but unreliable intellectuals. More concretely, the cadres turned the official understanding of intellectuals into distinct patterns of work, opportunity, and social association within the school system, or social boundaries saturated with the political meanings and moral values used by the party to define the subjects since the Yan'an phase of Chinese Communism. Three types of activity of the cadres were especially influential in this regard: their reassignment of roles and responsibilities, their enforcement of curriculum and other institutional changes, and their interaction with faculty and staff members.

The CCP takeover of the SBE during the summer of 1949 involved objectifying significations that would spread across the school system. The cadres assigned to the bureau were former underground agents of the party within the city or members of the PLA contingent. ${ }^{21}$ Although the crumbling Guomindang government left behind 383 employees in the bureau, the cadres retained the service of only 54 for accounting, mimeograph, and other technical tasks. ${ }^{22}$ The dismissal of the rest of the staff, which included educational program directors, campus inspectors, and other kinds of officers, cast the dismissed immediately as unfit for guiding socialist reform of the primary or secondary school system or other programs directed by the bureau. The latter's treatment of the dismissed suggested further to these persons that, based on the Marxian thinking of the party, they were a variety of inferior class subjects. Reflecting the Mao regime's concerns for social stability and political control with regard to the takeover of the city, the cadres arranged retraining and financial subsidies for almost three hundred people. This group underwent self-criticism, political study, and other ideological reeducation activities that targeted self-centeredness, materialism, and other habits and dispositions which the Mao regime alleged to be widely shared among intellectuals. After several weeks, the SBE provided eighty-four people with placement assistance, half of them for positions outside Shanghai. In particular, nine were recommended for Russian-language training or enrollment in a "revolutionary university" established by the party. These individuals were given exceptional assistance that probably allowed them to envision themselves serving the state again soon in some respectable capacity. By contrast, the SBE handed over the information of eight "reactionary elements" to the police for further investigation and even arrest, because "irrefutable evidence of repulsive activities" existed against these people. Based on their performance during retraining and other factors, the rest received dismissal subsidies (qiansan fe) or return-home subsidies (huixiang fe), or were put on a waiting list for job assignment. ${ }^{23}$ 
Across the secondary schools, official reorganization of roles and responsibilities signaled to faculty and staff members that the emerging state considered them heretofore allies of the exploiting classes. The SBE introduced management by CCP cadres through removing school principals from office or hollowing out their work and authority. The bureau's plan was to have every campus led by at least one experienced party cadre with support from a score of junior cadres. By 1954, almost 430 party cadres served across the schools. ${ }^{24}$ Two years later, 73 percent of the 200 campuses had a party cadre serving as principal or deputy principal..$^{25}$ Ordinary faculty or staff members rarely enjoyed upward mobility during this period, even though the expansion of the school system created many managerial positions. Even the small number of faculty and staff selected by the SBE for career development purposes because of their favorable background and quality of work, or those regarded by the bureau as most desirable among "progressive elements," did not escape everyday stigmatization as usable but unreliable intellectuals. Despite assumption of significant responsibilities after receiving official training and even recruitment into the party, few of these faculty or staff members gained top campus positions, as they were usually reserved for party cadres assigned from elsewhere. ${ }^{26}$

On the campuses, other mandated changes embodied and expressed official criticism of the faculty and staff as previous partners of the exploiting classes and functionaries in their ruling apparatus. Swiftly abolished were curriculum items required, sponsored, or controlled by the Guomindang regime based on its political, cultural, and moral visions, including the system of "character-development education" (xunyu zhidu) in public schools as well as scouting, military training, and civic instruction and their related classes, rituals, and events. ${ }^{27}$ As Robert Culp has noted, these programs and activities were introduced into the school system at various junctures of the Republican era (1912-1949). They were influenced by Continental European, Anglo-American, and traditional Chinese models of education and "could variously be characterized as liberal, Confucian, authoritarian, or fascist." ${ }^{28}$ Their elimination had symbolic impact inside and outside the school system, as did the official abolition of the teaching of Christianity, takeover of missionary schools, and reduction of English instruction as well as the mandated tuition cuts in the large numbers of private schools. The changes suggested that the ruling classes and even the imperialist powers had exploited the campuses and their workforces to propagate values and practices at the expense of Chinese society. Likewise, the rapid expansion of student enrollment orchestrated by the SBE to include "children from peasant and worker families," by relaxing age restrictions and academic standards, reinforced the official criticism that the faculty and staff had mostly organized the campuses to serve landlord, capitalist, and petty-bourgeois families. Within three years after the CCP takeover of Shanghai, the proportion of secondary students from underprivileged backgrounds had reportedly increased from 12 to 26 percent, or roughly from 9,00o to over $33,000 .{ }^{29}$ 
Inside the schoolhouse, everyday interaction between CCP cadres and the faculty and staff signaled to these ordinary professional workers that they were at best petty-bourgeois intellectuals as described in official discourse. Let us briefly look at the backgrounds of the cadres, which was a main reason why they acted the way they did. The cadres did not take over campus management because of any of their conventionally acceptable qualifications (e.g., college education and teaching experience), even when they had such qualifications; they were appointed by the state without consultation with the faculty and staff. In fact, the cadres generally lacked professional experience and academic credentials compared with the displaced school principals and administrators, an achievement gap exacerbated by the dearth of CCP cadres in the wake of the revolution as well as competition for their service across sectors..$^{30}$ Equally significant, many of the campus cadres shared family and occupational backgrounds similar to those of faculty and staff members. The 39 cadres who took over the SBE were former schoolteachers, office workers, or secondary students. ${ }^{31}$ By 1958 , even after efforts to improve the class composition of campus leaderships, the bureau noted, only 27 of 73 full-time party secretaries in secondary schools were from worker or poor-peasant families; the rest were raised in petty-bourgeois, bourgeois, or landlord families. Among 356 school principals, over 70 percent of whom were party members, only 76 were from the "exploited" classes. ${ }^{32}$

To secure their newfound but problematic authority, the cadres often resorted to what Bourdieu identified as elementary forms of domination, or pointed, coarse, and even brutal tactics of management that commonly follow a dramatic change in the authority structure. ${ }^{33}$ The tactics allow rulers to reproduce conditions of domination (e.g., fear and retreat among the ruled) when objective mechanisms (such as law, convention, or consent) have yet to mature to the extent of normalizing the hierarchy. From early on, the SBE reported, the campus cadres tended to adopt a hostile approach toward the faculty and staff. They wanted to expose wrongdoers of all kinds and see them officially punished together with those who continued to promote the interests and ideas of the exploiting classes. ${ }^{34}$ The hostility served to produce symbolic profit ${ }^{35}$ for the cadres, or recognition on and even off campus that they were different from as well as superior to other faculty or staff members. Thought Reform and other state campaigns that targeted "intellectuals" and exposed their alleged wrongdoing and undesirable habits and dispositions apparently emboldened the cadres, even as the SBE repeatedly instructed them to act firm but collegial inside the schoolhouse. After Thought Reform, the bureau conducted a study of private secondary schools, which still accounted for roughly half of the campuses in the school system. It discovered that instances of party cadres violating the official policy of "uniting, educating, and reforming intellectuals" were "rather common as well as extremely serious." Some cadres were full of "sentiments of arrogance and self-content." They verbally abused faculty and staff members, labeling them "shameless" and "backward," and even questioning their 
presence in the teaching profession. ${ }^{36}$ Roughly a year later, the SBE reported that "the relations between the party and the masses [i.e., between school cadres and the ordinary faculty and staff] are generally not good." The case of principal Ji Bin at Yangjing Secondary School suggests the extent to which some cadres would go to distinguish themselves from their colleagues. Ji's "brutal" (cubao) treatment of faculty and staff members had been so unacceptable that both the district-level and the city-level commission set up by the party to investigate the conduct of its members had already forced him to undergo self-criticism and other educational activities. His behavior on campus changed little afterward, as he continued to "discriminate" and lashed out against "backward instructors." 37

Social distancing, which can be interpreted as "a kind of informal ostracism," 38 was another common approach adopted by school party cadres toward the ordinary faculty and staff. Like public condemnation, the conduct supported the image that the cadres were officials overseeing intellectuals. The primary tactic of social distancing was apparently refusal to participate in instructional matters, or the central function of a profession which the state described as filled with petty-bourgeois subjects. During the early 1950s, the SBE observed that "primary and secondary school principals [who were CCP members] generally do not take care of matters directly related to classroom instruction." 39 They concentrated on handling official campaigns, financial and construction issues, and hiring, discipline, and other personnel matters. ${ }^{40}$ To be sure, many of the national campaigns that penetrated Shanghai secondary education led to multiple levels of investigation and cases of punishment. Appointment, budgeting, space, and other issues surged forth because of unprecedented increases in student enrollment. School principals justifiably complained to the SBE that there were "too many assignments with too little explanation, too-tight deadlines, and too numerous changes." ${ }^{41}$ Meanwhile, lack of teaching experience could not but prompt some principals to avoid instructional matters. However, refusing to act in the role of schoolteacher was also another creative way for the cadres to enact social boundaries, or present themselves as different from other faculty or staff members. To the dismay of the SBE authorities, a follow-up survey of nine secondary schools conducted in the mid-1950s indicated that the school principals still failed "to go deep into classrooms or grade levels" to give lessons, advice, or study directions. ${ }^{42}$ These party cadres, instead, let other party members take over instructional matters, with some of them exhibiting similar disaffection toward the responsibilities. Consequently, some of the schools used instructors who were not favored by the bureau to provide pedagogical leadership. Even when the bureau asked leading campus cadres to take charge of the instruction of socialist politics and values for students' benefits, a task that these party members were seemingly most qualified to perform, some cadres ignored that responsibility, too. At China Secondary School, for example, the cadres did not give any lectures on the topic. They employed, instead, "unreflective campaign-like approaches," which included 
bringing visitors to the campus to speak to students, as many as eleven times during one recent semester. ${ }^{43}$

Other forms of social distancing orchestrated by school party cadres also served to objectify ordinary faculty and staff members into usable but unreliable intellectuals. Even though the party cadres had access to policy information and state resources through the SBE, some offered little advice or assistance to their colleagues, while the latter faced unfamiliar political and economic challenges as a result of the revolution. What reportedly occurred at Yan'an Secondary School during the mid-1950s is instructive. Six party cadres were present on this relatively large campus, a number comparable to other schools of similar size. The cadres served as school principals, personnel executives, or instructors on socialist politics and held other influential posts. In political terms, the campus was hardly an extremely challenging place for management. Only 10 of the 73 people on the faculty and staff were "reactionary" or "backward elements." Nonetheless, the bureau remarked, the cadres lacked "compassion, regard, and patience," or proper sentiments deemed to be necessary for "assisting, educating, or nurturing" their colleagues in officially recommended ways. None of the 20 "progressive elements" on campus received training, support, or opportunities from management that would help them to become party members. The cadres, instead, "exploited" (shiying) the enthusiasm and energy of these people to help themselves run the campus. ${ }^{44}$

Using Yan'an Secondary School further as an example, the SBE emphasized two other areas in which the conduct of school party cadres was unsatisfactory. Faculty and staff members sometimes turned to the cadres for assistance when confronted with housing, subsistence, and other livelihood issues, since the state increasingly controlled job assignment as well as salaries and benefits within the school system,. Regardless of merits of a given request, the bureau discovered, the cadres at Yan'an responded poorly. They withheld subsidies and other forms of assistance established by the bureau, labeled the applicants "backward," and accused them of having a "purely economic perspective on life" (chun jingji guandian), which was a refrain used by the state to describe the petty bourgeoisie. A vice principal even stated that the campus had been "wasting money" by supporting an ill instructor with 60 percent of his salary. The other issue raised by the SBE had to do with ideological reeducation of the faculty and staff, which the state considered extremely important given that they interacted with students on a daily basis. The cadres at Yan'an, like those on other campuses, received official training periodically on how to help the faculty and staff to improve their political thinking and understanding of Chinese Communism. The bureau found out that the cadres did virtually nothing after returning to the campus from the training sessions. They passed on official directives during meetings with faculty and staff members without providing any guidance on understanding the content, let alone practicing the recommendations. They did not organize on-campus activities or take advantage 
of off-campus events for instructional purposes. When faculty or staff members asked for advice, the school principal told them to work harder to comprehend the material themselves. The bureau noted that some faculty, furthermore, had quite unpleasant interaction with the cadres. "[The cadres] cannot bear the sight of aged (laonian) teachers; they always highlight the backwardness of these teachers and fail to recognize their strengths. Even when they see the strengths, they do not offer any praise. With the teachers who are classified backward, the cadres cannot hide their disgust. They give up educating these people and set them adrift." 45 Some of the cadres on the campus continued to tell others that punishment was needed for the faculty or staff members who had cooperated with the Guomindang or other regimes.

In effect, the cadres who headed the campuses extended the class difference that CCP leaders had long constructed between themselves and other educated people - that is, proletarian revolutionaries versus petty-bourgeois intellectualsto their own everyday interaction with faculty and staff members. Like those of the party leaders, the efforts of the cadres to consecrate themselves as such revolutionaries at the expense of colleagues were not always successful. The educational achievement of the cadres and their professional responsibilities in the school system made them vulnerable to attacks, especially from superiors who were engaged in their own self-consecration. These party officials attacked some of the campus cadres, similar to how the latter turned ordinary faculty and staff members into targets. What happened to deputy principal Pan Lengyun of Dunhua Primary and Secondary School is an excellent example. In March 1955, together with two other commissions, the district-level CCP commission of disciplinary inspection that supervised her work issued a report after a "preliminary investigation." The commissions criticized Pan for using the tactics of punishment, insult, and distancing mentioned above. Although the report did not label Pan a pettybourgeois intellectual, it included many complaints used by the party to describe such subjects since the Yan'an period of Chinese Communism, and therefore left little doubt with regard to how the authorities thought of her. After being transferred to the campus, Pan gradually became "very arrogant and complacent" as well as "subjective, inflexible, and irascible." Above all, she displayed "the syndrome of a self-styled hero." On the one hand, the commissions observed, Pan did not "rely on [the advice of] the party or its organizations." She refused to study or implement official instructions on how to work with intellectuals. On the other hand, she was "divorced from the masses." She brushed off even "well-grounded ideas and assessments" from faculty and staff members. What she wanted were "grandiose achievements to make herself noticeable" by peers and superiors. To rectify the situation, the commissions recommended "severe criticism" of Pan and the transfer of a few "capable" party cadres to the campus to restore proper control. ${ }^{46}$ In other words, the commissions regarded Pan as a flawed but usable intellectual. 


\section{STRATEGIES OF STIGMA MANAGEMENT}

As a classification of people under the early PRC, the intellectual marked the classified with what the state pronounced as class traits, or an assortment of so-called petty-bourgeois and bourgeois habits and dispositions deemed to be harmful to Chinese Communism. We have seen that the CCP cadres assigned to Shanghai secondary education were aware of their vulnerability to being treated by superiors and colleagues as petty-bourgeois intellectuals. Some exploited their official positions and authority to set themselves apart from the ordinary faculty and staff. Here we look at how the faculty and staff and other professional workers negotiated the stigma associated with their official classification as intellectuals. Compared with the cadres, these persons did not have symbolic resources based on active political participation in Chinese Communism or access to administrative means to fend off the dubious classification. Nevertheless, stigma management flourished within this discredited population of "intellectuals" due to their attempts to resist or test CCP rule or to benefit or protect themselves from it.

Let us return to the aftermath of the immediate dismissal of more than $300 \mathrm{SBE}$ employees when the PLA seized Shanghai in 1949. Though shocked and dismayed, the majority of the dismissed enrolled in the retraining program offered by the bureau in hopes of receiving financial and employment assistance. They encountered for the first time ideological reeducation organized by the CCP, learning in a formal setting its interpretation of class and the latter's relations to Chinese society and global history. In addition, they participated in self-criticism and other activities built upon the critical view of intellectuals of the party. The SBE's analysis of how these former employees behaved during the retraining provides an otherwise unavailable glimpse at their initial reactions to stigmatization as usable but unreliable intellectuals. Former ranking officials turned out to be most defiant toward the denigration of their knowledge and experience. They took advantage of ongoing uncertainty involving the CCP takeover of Shanghai and the mainland as well as their former professional status and understanding of the bureau to fight off stigmatization in general and ideological reeducation in particular. According to the bureau:

[The former ranking officials] assumed airs of superiority, considered themselves always in the right, and refused our [ideological] reform. They turned up at events to see whether there were opportunities [to rebuild their careers] ... and listened to reports only when they did not reject the speakers. They indulged in high-sounding but meaningless talks, nitpicked at the words and phrases of others, and declared their own view to be "objective" and "above politics." They [disputed what they were taught and] claimed that the Soviet Union is as imperialistic as the United States, and that [all] political parties and factions are tools of people who seek power and money. They pretended to be exploring political thought and doctrines and insulted and rejected our [teaching based on Marxist-Leninist] theory. ${ }^{47}$ 
Other former SBE employees who underwent the retraining apparently submitted to official stigmatization without accepting its claims. The overwhelming majority, the bureau stated, went along with the program but saw it merely as a path to return to work. A few used "every means" to present themselves as "progressive" to get the authorities' attention. Some tried to "poison" the cadres' minds with agreeable words and deeds in attempts to conceal "evil acts" of exploitation or counterrevolution that they had committed. Only a small number genuinely wanted to "reform" and "strengthen" their political thinking. Outnumbered by others, they "did not have the courage to debate or defend the truths [that they noticed in Marxist thought]."48

Within primary and secondary schools, similar defiance, manipulation, and acceptance of official stigmatization arose. Roughly a week after the PLA seized Shanghai, SBE officials met with some faculty and staff members about placing their campuses under the bureau's control or direct supervision, thus signaling distrust of existing personnel. Some of those approached sided with the officials and even demanded in front of them the firing of public school principals, seizure of private schools controlled by "reactionary elements," and "exposure and condemnation of diploma mills." These persons acted in what they considered a cooperative manner. While some continued to support the emerging state, others changed their minds or remained defiant after realizing that the official attack on intellectuals could harm their own careers and professional authority. Some even started to work with "backward elements" to resist mandated campus reforms. ${ }^{49}$ As the bureau removed school principals, seized some campuses, and forced the closure of others, some continued to defy official instructions of reform. In March 1950, the SBE formally launched political study classes within primary and secondary schools after months of sponsoring related instructional activities. The bureau's goal was to gather faculty and staff members regularly on campus to study official material on class, politics, and history and learn about state policies and activities. Over thirty "study committees" staffed by 470 faculty and staff members were shortly formed across the city for supervisory and administrative purposes. ${ }^{50}$ The bureau discovered that the faculty and staff on some campuses refused to meet with visiting members of the committees, while those on other campuses deliberately appointed persons with no instructional responsibilities to receive the representatives or disregarded their instructions and advice altogether. The representatives had to return to some of the schools up to five or six times before seeing genuine efforts to set up political study properly. Elsewhere, the bureau observed, faculty and staff members approached political study with a "perfunctory attitude." They did not read the assigned texts or attend small-group meetings. They used instructional or administrative work as excuses for their absence, and even preferred to "waste their time on chitchats and watching [lewd] American 'thigh' movies." 51 Others attended the meetings but did not utter a single word. The SBE reported that reactions to political study in missionary schools were especially offensive. During discussion sessions, "backward" instructors received applause 
for their "oppositional views" from colleagues who had otherwise remained silent. Some school principals and directors of instruction "adopted a hostile attitude" toward the Resist-America-Aid-Korea Campaign organized by the state after the Korean War broke out, and even declared that they had views about the war different from that of the state. ${ }^{52}$

When Thought Reform of Intellectuals started to spread across Shanghai's cultural and educational sectors in 1952, open defiance against official policies and measures by ordinary professional workers and against their stigmatization by the state as petty-bourgeois intellectuals was no longer a safe course of action. State violence during the Campaign to Suppress Counterrevolutionaries had resulted in hundreds of execution and thousands of imprisonment in Shanghai. ${ }^{53}$ Across rural schools alone, the SBE reported in July 1951, ninety-nine people had been arrested and three sentenced to capital punishment. ${ }^{54}$ What Goffman termed as "covering" emerged as a major strategy of Thought Reform participants to cope with the stigma forced further upon them. While the participants did not dispute or deny the selfishness, indiscipline, or other shortcomings alleged by the state, many sought to keep these attributes from "looming large," 55 that is, spotlighted by others to the extent of endangering their own careers, livelihoods, or safety. One common tactic of covering was redirection during self-criticism, or the steering away of negative attention from the self. Some participants reportedly brought up multiple problems in their personal outlook, lifestyle, and political thinking, but indicated that these were consequences of broader patterns of belief and practice, or conditions in their family, workplace, social networks, and even Chinese society. ${ }^{56}$ Some "dwelt on minor flaws" in their personality, sometimes in colorful terms, as means "to hide major wrongdoing" or their support of the exploiting classes. ${ }^{57}$ Some "mechanically repeated" phrases and ideas from selfcriticisms published in newspapers and avoided talking about their own background, activities, or thoughts..$^{58}$ Some even changed their appearance to highlight their agreement with official ideology. Some schoolteachers, for example, "shaved their heads" and started wearing "running shoes" to project "the appearance of a veteran worker." ${ }^{59}$ Like what revolutionaries had done in Yan'an, especially after the Rectification Campaign, these individuals covered up their previous appearance. Others worked together to prevent political or moral issues uncovered by the state from hurting one another, a method that the authorities derided as the "pursuit of collective harmony" (yituan heqi). ${ }^{60}$ The following exchange illustrated in Wenhui Daily was apparently common when college instructors were asked to read one another's writings and identify and criticize ideological mistakes.
A: Professor X, did you not slander the Soviet Union in your work Y?
B: Where? Where? That's not true.
C: From what I know, it's perhaps an overstatement to call it a slander. However, it's completely obvious that it's a criticism of the Soviet Union.
D: Hmm, yes. ${ }^{61}$ 
Concealment of personal details, which often coexisted with redirection, was another tactic of covering used by professional workers to reduce stigma. Here the individuals sought to hide backgrounds in politics or other areas that they believed to be objectionable by official standards. They wanted to be recognized at worst as petty-bourgeois intellectuals. Zhu Shouzhong was an example. He was the CCP cadre who did not disclose to the higher authorities his official classification as an absentee landlord. While Thought Reform was underway, the Shanghai authorities found out that some participants "who are clearly from the landlord class by family background insist nevertheless that their class status is at worst middle-peasant; others who obviously belong to the bureaucratic-capital class portray themselves blithely as members of the petty bourgeoisie." ${ }^{22}$ Covering of personal details took other forms, too. Some Thought Reform participants reportedly glossed over various aspects of their background (e.g., political activities, friendships, hobbies) during self-criticism by offering vague or empty accounts. ${ }^{63}$ Some underreported their age in order to hide things they had done in the past. Some talked about their hardships, honesty, and charitable deeds to imply that they had not supported class exploitation. Some pinned "severe [ideological] labels" (da maozi) on themselves, such as extreme indiscipline or hedonism, to draw attention away from other conduct or activities of theirs. ${ }^{64}$ The SBE reported that when the last group of secondary school faculty and staff members took part in Thought Reform, comprising some 1,500 people, many arrived with prewritten autobiographical narratives and self-criticism, wanting to ride out the campaign without fully disclosing their backgrounds, activities, or thoughts. ${ }^{65}$

During Thought Reform, "self-exposure" was another strategy used by professional workers to negotiate their officially imposed stigma. Rather than bury details that would confirm shortcomings alleged by the state, some broadcast their mistakes and misdeeds with little prodding from party cadres. They wanted to convey comprehension of official ideology as well as cooperation and contrition, or be seen as working to turn over a new leaf. Although suitable for those who did not work closely with the Guomindang or other political regimes, self-exposure, like covering, was a difficult balancing act. The confessors had little control over how their cooperation was interpreted. The authorities sometimes saw the confession as yet another routine in the self-serving repertoire of petty-bourgeois intellectuals. It was believed that some participants disclosed offensive beliefs and behavior, not because they wanted to reform themselves politically, but because they wanted to show everyone else how "courageous" and "honest" they were. ${ }^{66}$ The authorities were unimpressed with others who allegedly resorted to histrionics, through "crying their heart out" and declaring that "they deserved a thousand deaths for their crimes." Other participants reportedly submitted themselves to criticism by choosing wrongly not to contest any complaints and even false accusations leveled against them by colleagues. ${ }^{67}$ 
While use of covering or self-exposure by ordinary professional workers to cope with official stigmatization reflected fear, anxiety, shame, confusion, or other emotions that they experienced, another strategy, "going on the attack," not only involved some of these reactions; its deployment deepened conflict and resentment within the workplace. With this approach, one played an aggressive role during mutual criticism or other activities to demonstrate cooperation with the state. Some Thought Reform participants reportedly adopted a "severe" and "leftist" attitude from early on. They loudly accused colleagues of multiple crimes and mistakes, "banged on the table and kicked the bench" to express their indignation, and used "severe labels" indiscriminately against the targets. The authorities were critical of such viciousness apparently as much as what they dismissed as insincere ready admission of wrongdoing. Some attackers, it was noted, "put on a show to deceive people" about who they really were, besides confounding facts with fiction in their complaints against others. For the state, even when the complaints were accurate and the attackers were forthcoming about their own wrongdoing, they still violated the intents and purposes of thought reform, which was "an endless and self-conscious process of discovery" of the truths in Marxist theory, working-class experience, and the Chinese socialist revolution. The state had multiple mechanisms in place to ensure that the reeducational activities introduced in the campaign would become "an integral part of the everyday life" of intellectuals, "much like eating, washing one's face, and sleeping." ${ }^{8}$ To the attacked, the experience was harrowing, even for those who had tried self-exposure. The attacked were "often flushed with shame and anger and were unhappy and dejected." They felt that the badgering and embarrassment was unnecessary. Many "promptly despised" the attackers, believing that they were "too backward" and "too confused" to understand thought reform and the consequences of their actions. Some confronted their attackers afterward. Some waited for their turn and took revenge. They hit the attacker with "a head-on blow," "randomly reprimanded him," and labeled him "reactionary." 69 To salvage their own reputation, some exaggerated the wrongdoing of the attackers and even gathered "trumped-up charges" to discredit these people. ${ }^{70}$

As Thought Reform proceeded, the authorities discovered another unpleasant trend. Ridicules, innuendos, and gossiping flourished, occurring regularly "over a cup of tea or after a few glasses of spirits" as the participants congregated during recesses or after work. The participants mocked colleagues openly or behind their backs on the basis of the revelations about desire, dalliance, or deviance, for example, yearnings to be rich, affairs with neighbors, and acts of embezzlement. Some "added inflammatory details" to what they had heard or "stitched together fragments" of material to spread rumors about colleagues. ${ }^{71}$ We have seen this kind of finger-pointing behavior among veteran revolutionaries in Yan'an and school party cadres in Shanghai. When the subjects found themselves vulnerable to 
stigmatization as petty-bourgeois intellectuals, they combined official values with those of their own to belittle colleagues as means of elevating themselves within their own minds, among their peers, and inside their profession.

Regardless of how Shanghai schoolteachers or other professional workers reacted to official stigmatization, the state's interpretations of their conduct, as we have seen, reinforced their assigned status as usable but unreliable intellectualsbecause of what Dorothy Smith identifies as "the circularity of the ideological process" commonly associated with hierarchical forms of administration. After publicizing widely the CCP discourse of class, the Shanghai authorities used this "predetermined conceptual framework" to illustrate in newspapers, internal reports, and other channels how professional workers responded or failed to respond to the requirements of Thought Reform and other ideological reeducation activities, or addressed self-centeredness, materialism, and other personal shortcomings. "Issues, questions, and experiences" that did not fit how the party understood class were simply left out of the official analyses..$^{72}$ Rendered illegible in these innumerable accounts were, especially, profound changes in work and governance because of the revolution and their impact on how the workers reacted to official stigmatization, not to mention personal, familial, and other factors.

Research has examined the urban workplace under the early PRC for good reasons. ${ }^{73}$ The site was central to the CCP pursuit of socialist development. The accounts describe key mechanisms of official domination such as central planning, management by party cadres, and ideological reeducation. They illustrate major patterns of conflict, cooperation, and inequality (for example, those related to party cadres and between party cadres and the ordinary staff) as well as individual and collective responses to official governance (e.g., pride, criticism, protest). The scholarship, however, does not explain how classes portrayed in the official discourse became everyday recognizable populations inside the workplace, or how jobholders assumed legible class identities. In comparison, studies of the countryside have spotlighted how land reform produced "landlords," "poor peasants," and other Marxian categories of people paradoxically as the party abolished conventional and capitalist economic relations. These studies underscore the role of official classification and pertinent institutional mediums (such as mandated selfreporting, investigation, and mass assemblies orchestrated by the party) as well as ambiguities and manipulations involved in the process. ${ }^{74}$

With a focus on the creation of petty-bourgeois intellectuals in a postrevolutionary school system, this chapter has suggested that the urban workplace occupied the center of the production and reproduction of the social classes envisioned by the Mao regime. To borrow a metaphor from Foucault, the school system became "a sort of artificial and coercive theater," one in which tens of thousands of ordinary people eventually assumed the character of the intellectual based on the Marxian 
view of the state. ${ }^{75}$ Scripts, designs, props, and dramas, as it were, inundated the school system. The CCP discourse of intellectuals (the primary script) permeated the system because of a variety of organizational rearrangements (or designs) mandated by the state, such as a new division of labor, thought reform, political lineups, and mass surveillance. The official use of multiple administrative tools (or props) - for example, official directives, personnel reports, statistical summaries, confessional statements, and autobiographical narratives-reproduced the discourse. An unending array of dramas with classification effects appeared: official accusations, self-consecrations, mutual antagonisms, judicial prosecutions, selfdeprecations, withdrawals, and so on. Everyone within the school system doubled as a cast member as well as an audience member in a thickening plot of class struggle prepared by the state, the punitive authority of which guaranteed the production. Relearning about the self, colleagues, and Chinese society took place as the performance unfolded. Like official classification in the countryside, ambiguities and manipulations with regard to class identity arose.

Equally important, we have seen that because the Mao regime pictured usable but unreliable intellectuals as an integral part of the workplace, management by CCP cadres, ideological reeducation, and mass surveillance flourished. The institutions became the official means to protect Chinese Communism from these subjects as much as to cultivate it with their knowledge and skills. Within the school system, the institutions made possible the revision of academic curricula, the expansion of student enrollment, the reassignment of responsibilities, and, more generally, experimentations with socialist education. At the same time, the institutions enabled the official condemnation and increasing suppression of the alternative political and moral views of the faculty and staff. In short, the institutions served to extend both the symbolic and the administrative capacity of the state.

What happened with the school system reveals that the objectification of the intellectual had seriously negative implications for Chinese Communism-by turning workplaces with professional workers into perpetual sites of official concern as well as internally divided organizations. The practice of textual corroboration engendered an unceasing flow of what the authorities regarded as evidence of work deficiencies, moral transgressions, criminal conduct, and political wrongdoing of professional workers, especially because the state repeatedly launched investigative and punitive campaigns. The practice of everyday signification produced and reproduced schisms, distrust, and resentment that undercut the potential of professional workers to cooperate with the state as well as with one another. Viewed in retrospect, the dynamics could not but lead to further turmoil. 